\title{
Career Progression Barriers of Female Staffs in Tanzania
}

\author{
Neema Mwalyagile \\ Mzumbe Mbeya Campus College, P.o.Box 6559 Mbeya, Tanzania \\ Email: nmwalaygile@mzumbe.ac.tz \\ DOI: $10.29322 / I J S R P .10 .08 .2020 . p 104100$ \\ http://dx.doi.org/10.29322/IJSRP.10.08.2020.p104100
}

\begin{abstract}
It is been half a century women's progression in professional career has been in a debate. Yet today, only scant percent of women are able to make their way at leadership and decision making positions at higher education institutions across the globe. However, women career in higher education has been of little concern to researchers. The purpose of this study is to examine the relationship between gender stereotype and social-cultural beliefs with women's career progression barriers among female staffs in a public university in Tanzania. This quantitative approach research has collected data from 300 female staffs of a public university using questionnaire survey. The study analyzes collected data utilizing Pearson correlation and multiple regression model to identify the relationship and test the hypothesis. The findings of the study reveal that gender stereotype, significantly influence the career progression barriers of female staffs. While social-cultural beliefs found to have an insignificant association, thus it does not affect career progression barriers of women staffs. This finding is believed to be logical in the context of Tanzania since it is a very inclusive and liberal nation.
\end{abstract}

Keywords: social-cultural beliefs, gender inequality, women, Tanzania.

\section{Introduction}

Women's progression in the workplace has taken significant strides in the past 50 years (Carr, Gunn, Kaplan, Raj, \& Freund, 2015; O'Meara, 2015). In the 1980s, the popular press, including The Wall Street Journal and Adweek, were among the first who began utilizing the term the glass ceiling,l in which reporters noted that, despite 15 years after gender discrimination was made illegal in some places, professional women were remain unable in climbing to senior positions (Hoobler, Lemmon, \& Wayne, 2011). Among many other organizations, currently, women in higher education are still underrepresented in senior level administrative positions in college campuses (Jawahar \& Hemmasi, 2006). Despite newly developed and suggested mentoring programs, professional development and leadership preparation, women in academia are still not getting along at the same pace as their male counterparts (Catherine Ehrich, 1994, 1995; Stanford-Blair \& Dickmann, 2005). Women persist bunched in low-level positions, midlevel administrative positions or positions more outlying to upgrade into central management, such as librarians and student services. The term -glass roofl was minted in the early 1980s in reference to artificial barriers to the promotion of women and people of color which prevent them from rising to administrative offices in higher academia (Hymnowitz \& Schellhardt, 1986; Oakley, 2000). In a study of female's in low paying work, Harland and Berheide (1994) discovered that adult females deliver a slim to zero likelihood to gain high enough to encounter the glass ceiling; instead, they are trapped by what Harland and Berheide termed the -sticky floorl low-pay low-mobility jobs (Harlan \& Berheide, 1994). Decision makers are often distinguished by their functional specialization, skills, and preparation (Rosser, 2000). Further distinction happens when groping the administrators' work environment: academic affairs (Jackson, 2004); student affairs (Jackson, 2004) and administrative affairs (Rosser, 2000)

\subsection{Literature Review}

Traditionally, women have taught preparing meals, caring husband, children and household chores and find happiness in these works. Home is the ultimate place for women to reside and devoting herself completely at the position of homemaker, that is the natural beliefs in many societies. This negative stereotype therefore, viewed career oriented women as irresponsible and morally wrong. However, working women no longer lag behind in most of the profession since today's society has changed drastically in the past few decades. Women employees are performing regular duties as assigned to men. Yet, it is believed that women employees experience glass ceiling as unsurpassable barriers in their career advancement (Ezzedeen, et al. 2015). On the other hand, the enrollment of women at schools, colleges and universities soaring higher than the past decade in many countries. Professional women are now actively participating in the national and world economy since the rate of female labor participation in nearly 50 percent in worldwide (ILO, 2016). However, this scenario doesn't imply the equal opportunities for women in the workplace, especially when it comes to the progression in the senior management level (Tlass \& Kauser, 2010). Generally, the 
number of female employees rises at the junior or middle management level in the UK and USA (Lyness, 2002), however, only scant portion progress experienced so far at the senior management level (Metz \& Simon, 2010).

Though female workers participate in the national economy, they usually face unequal earning distribution in the workplace. The Organization for Economic Co-operation and Development reported that women earn 16 percent less compared to men in OECD nations and it happens due to one tenth ratio of female board member in corporations (Organization for Economic Co-operation and Development, 2012, Mwandosya \& Mbise, 2019). Likewise, the World Economic Forum reported that no country has witnessed yet that achieved gender equality or eradicated gender gap in the shared decision making position (Matonya, 2018; Paton, Bullivant, \& Soto, 2020). Thus, it is no doubt that women employees face artificial barriers that limit their career advancement in the senior management level (Myerson \& Fletcher, 2000). In this regard, investigating on barriers that restrict women to progress in their career bears great significance in the educational institution, particularly in Tanzania. Higher education has become a necessity in many countries in attaining a higher standard in terms of social and economic development (Kinyaduka, 2019; Matonya, 2018). This is evident in the Tanzanian context as it is strategizing to become a first world economy nation by 2030, where the tertiary education is the foundation for natural development (Kessy, 2020; Nguni, 2020). The plans, which had been incorporated to lead the changes and developments in the Higher education in the country, were done in line with the National Mission. These national blueprints had emphasized on economic and social transformation so that Tanzania could achieve a high-income knowledge-based economy by the year 2030 .

Consequently, an empirical investigation of barriers to women's career advancement plays a significant role to underline the reason of female employees' slower and uneven career progress. A diversified group of staff and faculty at top management level is valuable to higher education institutions because it supplies a variety of role models, viewpoints and leadership styles. Thither is a demand for more women in senior level administrative posts in higher education to help close the gender g a p (Chliwniak, 1997). Thus, purpose of this study is to quantify the effect of gender stereotype, work-family conflict, socialcultural beliefs, organizational support, and individual characteristics on women's career advancement. The study also aims to identify the research gap in the higher education institution from Tanzanian context so that women's career could be improved through proper initiatives.

The scenario of global workforce shows that female counterpart is more successful in the top level management (Schein, 2007). The author noted that despite 40 percent plus share of women workforce worldwide, their portion of decision making positions remains unacceptably low. Unfortunately, strong believe and mindset about women's inability to hold senior corporate ladders and their lacking to operate any organization with taking the critical decision still available (Nguyen, 2013). Therefore, women employees in many countries are facing various barriers in their professional advancement since men are more likely to be authoritarian to hold those positions, hat certainly includes Tanzania (Dwyer, Kulasingam, Mwimbe, Dickson, \& Rogers, 2019; Mushi, 2014). This study aims to examine the factors that put obstacle for women employees to progress in their career. Several studies have believed there are various factors that can act as barriers for women, depending on context, that includes both country and industry where they stay (Jogulu \& Wood, 2011; Walsh, 2012). Among others, gender is one of the key factors in career progression (Henkel, 2017; Hernandez and Morales, 1999), thus the hierarchical association between gender types and employers is a critical matter (Rose and Larwood, 1988). Thanacoody et al. (2006) and Nguyen (2013) revealed that gender stereotype creates a barrier for women academics in Australia and Mauritius. Moreover, Wilson (2005) claimed that male still used to look female as having different and inferior qualitiesl in academia. These views of men lead them to hold higher position in academia and women suffer less progression due to gender stereotype (Nguyen, 2013).

Several studies have believed there are various factors that can act as barriers for women, depending on context, that includes both country and industry where they stay (Jogulu \& Wood, 2011; Walsh, 2012). Among others, gender is one of the key factors in career progression (Henkel, 2017), thus the hierarchical association between gender types and employers is a critical matter (Rose and Larwood, 1988). Nguyen (2013) revealed that gender stereotype creates a barrier for women academics in Australia and Mauritius. Moreover, Wilson (2005) claimed that male still used to look female as having different and inferior qualities\| in academia. These views of men lead them to hold higher position in academia and women suffer less progression due to gender stereotype (Eagly \& Carli, 2003; Nguyen, 2013).

In addition, social cultural beliefs and perception also shape women decision to work as well influence to take various professional decisions (Coogan, \& Chen, 2007; Mccray, Sindelar, Kilgore \& Neal, 2002). Ridgeway (2002) claimed that negative perceptions and beliefs that has extracted from the social and cultural background, even from religion are often created obstacle for women to progress. Feugen, Biernat, Haines and Deaux (2004) asserted that the social view toward working women during motherhood is violating the norms of caretaker role, whereas the working father is appreciated in the same context, thus dismiss opportunities for women to excel, but enhance scopes for the counterpart, family duties is another important determinant that can influence women's career progression in the academia (White, 2003). Ismail et al. (2005) asserted that women are often encountered with the difficulty of balancing their work-family obligations in an academic context and many unable to comply, thus witness a slower progression. Though other study argued that multi- tasks can improve an individual's skill and help to

This publication is licensed under Creative Commons Attribution CC BY. 
enrich with professional caliber (Ruderman et al., 2002). However, a notable number of researches revealed that the burden of balancing work and family is a major obstacle for women to progress (Jogulu \& Wood, 2011; Nguyen, 2013). In addition, social cultural beliefs and perception also shape women decision to work as well influence to take various professional decisions (Coogan, \& Chen, 2007; Mccray, Sindelar, Kilgore \& Neal, 2002). Ridgeway (2001) claimed that negative perceptions and beliefs that has extracted from the social and cultural background, even from religion are often created obstacle for women to progress. Feugen, Biernat, Haines and Deaux (2004) asserted that the social view toward working women during motherhood is violating the norms of caretaker role, whereas the working father is appreciated in the same context, thus dismiss opportunities for women to excel, but enhance scopes for the counterpart.

The social role theory has identified as an underpinning theory for this study. The theory describes the behavioral differences between men and women (Eagly 1987). According to the theory, differences in behavior happen from gender stereotypes, which are typical roles related to gender (Strodtbeck \& Mann 1956). The aim of this study is to examine barriers to women's career progression in a public university. Though this issue has been studied since long, but the appropriate answer to address the issue is still ambiguous and mixed picture is pointed. Therefore, this issue is still alive, especially women in the academic context has been attracting attention since number of current studies have focused on this issue (Henkel, 2017; Parker, Hewitt, Witheriff \& Cooper, 2018; Winslow \& Davis, 2016). Conversely, this study so far identified only one attempt to address this issue from the Malaysian academic context, however, their study was based on a qualitative survey to understand perceptions (Jogulu \& Wood, 2011). Thus, the on-going yet unaddressed issue of women's career progression barriers in the context of Tanzanian public university is justified for further examination.

\section{Gender Stereotype}

Generally, when people carry generalize thought about the roles and abilities based on gender that represent as gender stereotype. It is shared beliefs about the psychological traits of women and men.Thus, employees in the organization suffer by gender stereotype. Even it is not new that the evaluation of prospective candidate can be biased by gender stereotype in the organization (Heilman, 2001). Therefore, gender stereotype has been repeatedly used in many researches to understand why women lag behind to promote in leading and prestigious position in the organization (Heilman, 2001; Eagly \& Karau, 2002). Although women hired in a senior managerial position they usually distinguished as less agentic (achievement-oriented traits) than men (Heilman, 2001; Heilman, Block, \& Martell, 1995). Perception driven from the role congruity theory is that female face tough situation to obtain leadership positions than male (Eagly \& Karau, 2002). On the other hand, it is speculated that women employees have a lack of personal job fit which block them in acceptances for the senior management role and that is directed by the gender stereotyping perspective (Wood, 2008). For an instant; it has pointed that women employees are the front-liner in the tourism and hospitality industry. However, they are largely presented in clerical and service level jobs, but barely found at professional levels (United Nation World Tourism Organization, 2010), which indicates male are more likely associated with the role of managers in the tourism industry (Wood, 2008). The same story is observed in various other sectors as well.

\section{$H_{1}$ : Gender stereotype has a significant role in creating barriers on women's career progression}

\section{Social-Cultural Beliefs}

Social and cultural beliefs represent various aspects of today's society which splits women from their career progression. That includes religious and ethnic identity, ethical behaviour, social policies, relationship status, socialization of female and parenthood (Cooray \& Potrafke, 2011; Henning \& Pfau- Effinger, 2012). Women unable to prepare themselves to improve skills and take challenges due to socialization practices, hence, females remain lack of corporate educations and experiences which lead them to confined career opportunities (De-Leon, 1996). Moreover, implication of social cultural environment from the perspective of behavioural expectations has found influences women's career advancement and cultural attitudes toward professional female is suggested to quantify in previous research (Jamali \& Sdani, 2005). In many societies, cultural attitudes toward the role and status of women are still prevalent and it's quite impossible for many of them to dislocate from this cultural tradition due to fear of being ostracized (Kiamba, 2008). Likewise, working outside the home in many societies considered as the violation of cultural norms and traditions (Majanja \& Kiplang'at, 2003; Wood, 2008). Therefore, women's professional progression prospects are still considerably illiberal. In addition, traditional beliefs imply that men are the chief of the household, the breadwinner and possess the right of social life, whereas, women's role is caring household despite involving education and professional life (Sadie, 2005). As a result, cultural attitudes and beliefs toward women's progression in decision making position are adverse (Sadie, 2005).

\section{$\mathrm{H}_{2}$ : Social-cultural beliefs have a significant role in creating barriers on women's career progression.}




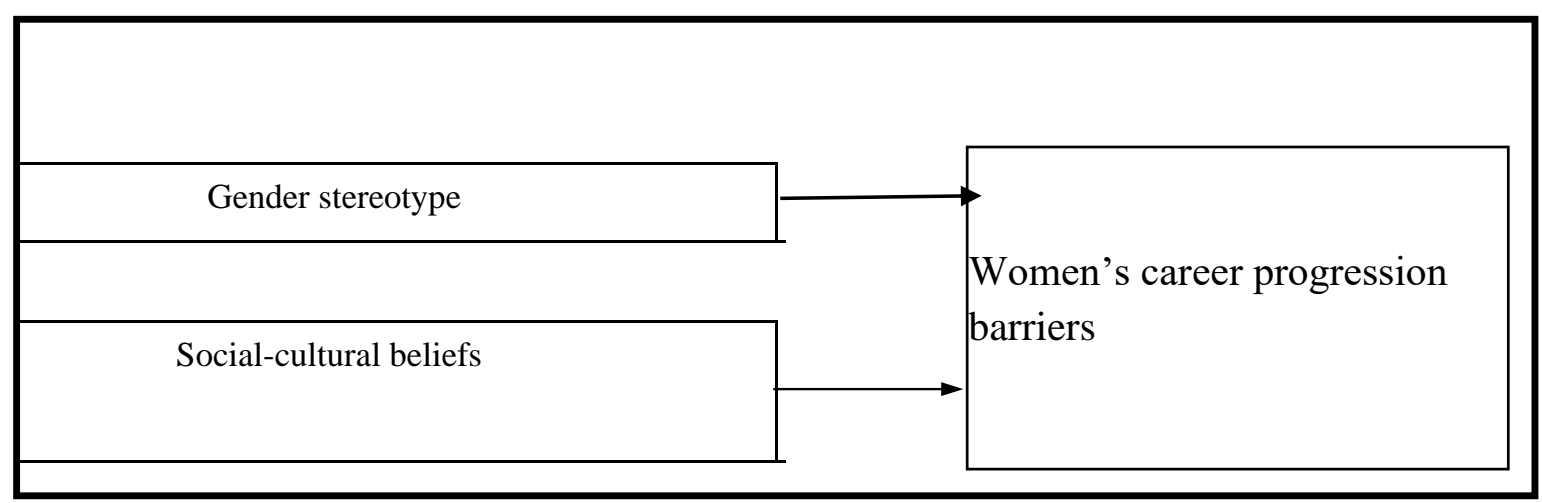

Source: Adapted (Cross, 2010). Figure .1 Research Framework

\section{Women's Career Progression Barriers}

The dependent variable of this study is women's career progression barriers. Swanson and Woitke (1997) refereed -barriers in this context as conditions or events, either internally alleged or seen in a woman's atmosphere, which hinder career progressll. Examples of such barriers include conflict between career demands and child caring, multiple tasks struggle, inadequate career prospects, limitation in adequacy of childcare, gender discrimination, and career selfefficacy. Another study defines, barrier to career progression as a factor, event or phenomenon that prevent or control access to individual women from making progress (Ismail \& Ibrahim, 2008).

\section{Gender Stereotype}

Gender stereotyping is the practice of ascribing to an individual woman or man specific attributes, characteristics or roles on the sole basis of her or his membership of the social group of women or menll. According to the United Nation Human Rights Office of the High Commissioner. A gender stereotype is a generalized view or preconception about attributes or characteristics that are or ought to be possessed by, or the roles that are or should be performed by women and men. Stereotypes are generalizations about groups that apply to group members simply because they belong to that group. Gender stereotypes are generalizations about the attributes of men and women (Heilman, 2015)

\section{Social-Cultural Beliefs}

It refers to a set of beliefs, customs, practices and behavior that exists within a population. The social-cultural perspective is a theory used in fields such as psychology and is used to describe the awareness of the circumstances surrounding individuals and how their behaviors are affected specifically by their surroundings, social and cultural factors. According to scholar sociocultural perspective: A perspective, describing people's behavior and mental processes as shaped in part by their social and/or cultural contact, including race, gender, and nationality (Ouellette \& Wood, 1998). Social-cultural beliefs which are made up of collection of activities and relationships through which people engage in their personal and private lives which include population features, age, ethnicity, religion, values, attitude, lifestyles and associates(Shumbusho, Henry, \& Sharon, 2020).

\subsection{Research and Methods}

The data obtained from the questionnaire survey are analyzed using Statistical Package for the Social Sciences (SPSS) version 23 to analyze the validity and reliability of the data and test the research hypotheses. All the incomplete questionnaires and data will be dropped from the data analysis to ensure the final data collection is worthy to enter into SPSS software for analysis. The analysis begins with descriptive statistics to present the data acquired in a structured, accurate and summarized manner. The descriptive analysis, which includes frequencies and percentages is used to analyze the demographic data. The demographic data, including job title, job level, age, marital status, education, ethnicity, husband, job sector and children status of the respondents. Similarly, the descriptive analysis also checked the frequencies of all independent and dependent variables included mean, standard deviation, maximum and minimum values. In addition, the five facets of barriers to women's career progression were measured for the reliability to check for the consistency and Cronbach's alpha coefficient was used to determine the consistency. The closer Cronbach's alpha value to 1, the higher the internal consistency reliability (Sekaran, 2003). The correlation between the independent variables and a dependent variable was determined through analysis, namely Pearson correlation two-tailed test. 


\section{0 Findings \\ Correlation Analysis}

According to Pallant (2011), correlation test is utilized to explain the strength and direction of the linear association between selected variables. Sekaran \& Bougie, 2009 asserted that Pearson correlation coefficient refers the direction, strength and significance of the bivariate relationship among the study. The Pearson correlation is denoted by letter $r$ and the value, ranging from -1 to +1 . Pallant (2011) suggested that the strength is determined as: $r=0.50$ to 1.0 is strong, $r=$ 0.30 to 0.49 is moderate or medium and $r=0.10$ to 0.29 is correlation for statistical significance.

Table 1

Pearson Correlation Analysis

\begin{tabular}{|c|c|c|c|}
\hline Variables & WCP & GS & SCB \\
\hline WCP & 1 & & \\
\hline GS & $.597^{* *}$ & 1 & \\
\hline SCB & $.515^{* *}$ & $.604^{* *}$ & 1 \\
\hline
\end{tabular}

**. Correlation is significant at the 0.01 level (2-tailed).

Note: $\mathrm{WCP}=$ Women career progression, $\mathrm{GS}=$ Gender stereotype, $\mathrm{SCB}=$ Social cultural beliefs.

Table 1 presents the outputs of correlation test between all independent variables with dependent variables. All independent variables show a positive correlation with the dependent variable. The highest correlation is reported between gender stereotypes and barriers to women's career progression at $r=.597(p<0.000)$ and $r=515(p<0.000)$ social-cultural beliefs. Overall, independent variables have shown a strong correlation with the dependent variable, therefore, these can be further analyzed for hypothesis testing.

The multiple correlation co-efficient $(\mathrm{R})$ between the dependent variable and the independent variables is 0.688 . Moreover, the coefficient of determination, $\mathrm{R}^{2}$ is reported .473 which indicates that 47.3 percent of the variance in women's career progression barriers has explained by these two independent variables analyzed in this research. The rest of the percentage $(52.7 \%)$ is explaining other factors that are left out of this study. The regression model is significant, with a probability level of 0.000 as evidenced in the ANOVA table.

Table 2

Results of Multiple Regression Analysis

\begin{tabular}{|c|c|c|c|c|c|}
\hline \multirow[t]{2}{*}{ Model } & \multicolumn{2}{|c|}{$\begin{array}{l}\text { Unstandardized } \\
\text { Coefficients }\end{array}$} & \multirow{2}{*}{$\begin{array}{c}\begin{array}{c}\text { Standardized } \\
\text { Coefficients }\end{array} \\
\text { Beta }\end{array}$} & \multirow[t]{2}{*}{$t$} & \multirow[t]{2}{*}{ Sig. } \\
\hline & $\overline{\mathbf{B}}$ & Std. Error & & & \\
\hline (Constant) & .531 & .225 & & 2.361 & .019 \\
\hline GS & $.338^{* * *}$ & .064 & .320 & 5.246 & .000 \\
\hline SCB & .065 & .060 & .070 & 1.087 & .278 \\
\hline .688 & $\begin{array}{l}\mathrm{R}^{2} \\
.473\end{array}$ & $\begin{array}{l}\text { Adjusted } \mathrm{R}^{2} \\
.463\end{array}$ & $\begin{array}{c}\text { Durbin-Watson } \\
1.424\end{array}$ & $\begin{array}{r}\mathrm{F} \\
46.29\end{array}$ & \\
\hline
\end{tabular}

Statistically significant at $* 10 \% ; * * 5 \%$ and $* * * 1 \%$.

Notes:

a. Predictors: (Constant), social cultural beliefs and gender stereotype.

b. Dependent Variable: Barriers to women's career progression.

This study hypothesized that gender stereotype has a significant relationship in creating barriers for women to progress. The regression results show evidence as hypothesized. Gender stereotype has a significant positive relationship with barriers to women's career progression where the coefficient is .320 and $p<0.000$. This study reveals that, there is an increase of 0.320 in gender stereotype for every unit increase in the barriers to women's career progression. Therefore, hypothesis 1 is accepted.

This study hypothesized that social-cultural beliefs has a significant relationship in creating barriers for women to progress. The regression results show reverse evidence than the study predicted. Social-cultural beliefs found to have an insignificant positive relationship with barriers to women's career progression where the coefficient is .070 and $p>0.05$. This study indicates that, there 
is no effect on social-cultural beliefs for any changes in the barriers to women's career progression. Therefore, hypothesis 2 is rejected.

\subsection{Recommendations}

Despite an insignificant evidence of socio-cultural beliefs, this study also identifies several strong associations between other independent variables and a dependent variable. Therefore, to resolve or minimize the issue for university staffs, this study places the following recommendation based on the findings. University management should promote fair and comfortable work environment for both male and female staffs. Management should provide opportunities for female staff to demonstrate their credibility that will not only increase their confidence, but will also reinforce to break the stereotype against women. The researcher has observed that women in Tanzania generally soft spoken, shy, easy going and prefer to stay in a comfort zone. Therefore, there will be two folds of initiatives. First, female staff has to be confident and outspoken, and should increase their self-esteem to take any professional challenge. Secondly, university management should engage female staff with more public activities, especially providing them to organize public events which will allow them to mingle with various types of people.

\section{Reference}

Carr, P. L., Gunn, C. M., Kaplan, S. A., Raj, A., \& Freund, K. M. (2015). Inadequate progress for women in academic medicine: findings from the National Faculty Study. Journal of Women's Health, 24, 190-199.

Catherine Ehrich, L. (1994). Mentoring and networking for women educators. Women in Management Review, 9 , 4-10.

Catherine Ehrich, L. (1995). Professional mentorship for women educators in government schools. Journal of Educational Administration, 33, 69-83.

Chliwniak, L. (1997). Higher Education Leadership: Analyzing the Gender Gap. ASHE-ERIC Higher Education Report, Vol. 25, No. 4. ERIC.

Coogan, P. A., \& Chen, P. C. P. (2007). Career development and counselling for women: Connecting theories to practice. Counselling Psychology Quarterly, 20(2), 191-204. https://doi.org/10.1080/09515070701391171

Cooray, A., \& Potrafke, N. (2011). Gender inequality in education: Political institutions or culture and religion? European Journal of Political Economy, 27, 268-280.

De Leon, B. (1996). Career development of Hispanic adolescent girls. Urban Girls: Resisting Stereotypes, Creating Identities, 380-398.

Dwyer, T., Kulasingam, S., Mwimbe, K., Dickson, K., \& Rogers, C. (2019). Risk - Taking Behaviors and Sexual Violence Among Secondary School Students in Tanzania. Journal of Community Health, 44(4), 749-755. https://doi.org/10.1007/s10900-019-00673-2

Eagly, A. H. (1987). Sex Differences in Social Behavior: A Social-role interpretation. Psychology Press.

Eagly, A. H., \& Karau, S. J. (2002). Role congruity theory of prejudice toward female leaders. Psychological Review, 109, 573

Eagly, A. H., Karau, S. J., Miner, J. B., \& Johnson, B. T. (1994). Gender and motivation to manage in hierarchic organizations: A meta-analysis. The Leadership Quarterly, 5, 135-159.

Ezzedeen, S. R., Budworth, M.-H., \& Baker, S. D. (2015). The Glass Ceiling and Executive Careers Still an Issue for Pre-Career Women. Journal of Career Development, 0894845314566943.

Fuegen Kathleen, Biernat Monica, Haines Elizabeth, \& Deaux Kay. (2004). Mothers and Fathers in the Workplace: How Gender and Parental Status Influence Judgments of Job-Related Competence. Journal of Social Issues, 60(4), 737- 754. https://doi.org/10.1111/j.0022-4537.2004.00383.x

Harlan, S. L., \& Berheide, C. W. (1994). Barriers to work place advancement experienced by women in low-paying occupations.

Heilman, M. E. (2001). Description and prescription: How gender stereotypes prevent women's ascent up the organizational ladder. Journal of Social Issues, 57, 657-674.

Heilman, M. E. (2015). Gender Stereotypes: Impediments to Women's Career Progress. In Auswahl von Männern und Frauen als Führungskräfte (pp. 73- 84). Springer Gabler, Wiesbaden. https://doi.org/10.1007/978-3658-09469-0 7

Henkel, M. (2017). Gender Equality in Academic Career Progression: A Matter of Time? The Changing Role of Women in Higher Education, 195-207. https://doi.org/10.1007/978-3-319-42436-1_10

Hennig, M., \& Pfau-Effinger, B. (2012). Women's employment in the institutional and cultural context. International Journal of Sociology and Social Policy, 32, 530-543. 
Hernández, T. J., \& Morales, N. E. (1999). Career, Culture, and Compromise: Career Development Experiences of Latinas Working in Higher Education. The Career Development Quarterly, 48(1), 45-58. https://doi.org/10.1002/j.2161- 0045.1999.tb00274.x

Hoobler, J. M., Lemmon, G., \& Wayne, S. J. (2011). Women's underrepresentation in upper management: New insights on a persistent problem. Organizational Dynamics, 40, 151-156.

Hymnowitz, C., \& Schellhardt, T. D. (1986). The glass ceiling. The Wall Street Journal.

ILO. (2016). Women at work: Trends 2016. Geneva: International Labour Office. Ismail, M., \& Ibrahim, M.

(2008). Barriers to career progression faced by women:

Evidence from a Malaysian multinational oil company. Gender in Management: An International Journal, 23, 51-66.

Ismail, M., Rasdi, R. M., \& Wahat, N. W. A. (2005). High-flyer women academicians: factors contributing to success. Women in Management Review, 20(2), 117-132. https://doi.org/10.1108/09649420510584454

Jackson, J. F. (2004). Toward a business model of executive behavior: An exploration of the workdays of four college of education deans at large research universities. The Review of Higher Education, 27, 409-427.

Jamali, D., Sidani, Y., \& Safieddine, A. (2005). Constraints facing working women in Lebanon: an insider view. Women in Management Review, 20, 581-594.

Jawahar, I. M., \& Hemmasi, P. (2006). Perceived organizational support for women's advancement and turnover intentions: The mediating role of job and employer satisfaction. Women in Management Review, 21, 643661.

Jogulu, U., \& Wood, G. (2011). Women managers' career progression: an Asia Pacific perspective. Gender in Management: An International Journal, 26(8), 590-603. https://doi.org/10.1108/17542411111183893

Kessy, A. T. (2020). Higher Education and Prospects of Graduates 'Employability in Tanzania. Journal of Education and Practice, 11(9), 177-187. https://doi.org/10.7176/JEP/11-9-19

Kiamba, J. M. (2008). Women and leadership positions: Social and cultural barriers to success. Wagadu: A Journal of Transnational Women's and Gender Studies, 6, 5.

Kinyaduka, B. D. (2019). Developing Responsibility for Learning in Higher Education in Tanzania : Experiences from Undergraduate Programmes, (February), 62-69. https://doi.org/10.20448/804.4.1.62.69

Lyness, K. S., \& Thompson, D. E. (2000). Climbing the corporate ladder: do female and male executives follow the same route? Journal of Applied Psychology, 85, 86.

Majanja, M., \& Kiplang'at, J. (2003). Women librarians in Kenya: a study of their status and occupational characteristics. Library Management, 24, 70-78

Matonya, M. (2018). Participation of Women with Disabilities in Tanzanian Higher Education: Motivations , Strategies and Suggestions.

Mccray, A. D., Sindelar, P. T., Kilgore, K. K., \& Neal, L. I. (2002). African-American women's decisions to become teachers: Sociocultural perspectives. International Journal of Qualitative Studies in Education, 15(3), 269-290. https://doi.org/10.1080/09518390210122845

Metz, I., \& Simon, A. (2010). A focus on gender similarities in work experiences in senior management: A study of an Australian bank builds the case. Equal Opportunities International, 27, 433-454.

Meyerson, D. E., \& Fletcher, J. K. (2000). A modest manifesto for shattering the glass ceiling. Harvard Business Review, 78, 126-136.

Mushi, H. M. (2014). The Effects of Cost-Sharing on the Quality Performance of Higher Education and Introduction of a Balance Score Cards in Tanzania. International Jounal of Innovation and Researchin Education Sciences, 1(2), 41-43.

Mwandosya, G. I., \& Mbise, E. R. (2019). Evaluation feedback on the functionality of a mobile education tool for innovative teaching and learning in a higher education institution in Tanzania Godfrey Isaac Mwandosya \& Esther Rosinner Mbise College of Business Education, Tanzania. International Journal of Education and Development Using Information and Communication Technology (IJEDICT), 15(4), 44-70

Nguni, S. C. (2020). Transformational Leadership in Tanzanian Education.

Nguyen, T. L. H. (2013). Barriers to and facilitators of female Deans' career advancement in higher education: an exploratory study in Vietnam. Higher Education, 66(1), 123-138. https://doi.org/10.1007/s10734-0129594-4

Oakley, J. G. (2000). Gender-based barriers to senior management positions: Understanding the scarcity of female CEOs. Journal of Business Ethics, 27, 321-334.

Organization for Economic Co-operation and Development. (2012). Closing the gender gap: act now. Organisation for Economic Co-operation Development.

United Nation Human Rights Office of the High Commissioner. (2014). Gender stereotypes and Stereotyping and women's rights. Geneva, Switzerland: Office of the High Commissioner for Human Rights. 
Ouellette, J. a., \& Wood, W. (1998). Habit and intention in everyday life: the multiple processes by which past behavior predicts future behavior. Psychological Bulletin, 124(1), 54-74. https://doi.org/10.1037/0033$\underline{2909.124 .1 .54}$

O’Meara, K. (2015). A career with a view: Agentic perspectives of women faculty.

The Journal of Higher Education, 86, 331-359.

Pallant, J. (2011). SPSS Survival Manual 4th edition: A step by step guide to data analysis using SPSS version 18. Maidenhead, Berkshire: Open University Press.

Parker, P., Hewitt, B., Witheriff, J., \& Cooper, A. (2018). Frank and Fearless: Supporting Academic Career Progression for Women in an Australian Program. Administrative $\quad$ Sciences, $\quad 8(1), \quad 5$. https://doi.org/10.3390/admsci8010005

Paton, D., Bullivant, S., \& Soto, J. (2020). The impact of sex education mandates on teenage pregnancy : International evidence. Health Economics, (March), 790-807. https://doi.org/10.1002/hec.4021

Ridgeway Cecilia L. (2001). Gender, Status, and Leadership. Journal of Social Issues, 57(4), 637-655. https://doi.org/10.1111/0022-4537.00233

Rose, S., \& Larwood, L. (1988). Women's Careers: Pathways and Pitfalls. New York, NY: Praeger Publications.

Rosser, V. J. (2000). Midlevel administrators: What we know. New Directions for Higher Education, 2000, 5-13.

Ruderman, M. N., Ohlott, P. J., Panzer, K., \& King, S. N. (2002). Benefits of Multiple Roles for Managerial Women. Academy of Management Journal, 45(2), 369- 386. https://doi.org/10.5465/3069352

Sadie, Y. (2005). Women in political decision-making in the SADC region. Agenda, 19, 17-31.

Sekaran, U. (2003). Research methods for business . Hoboken. NJ: John Wiley \& Sons.

Sekaran, U., \& Bougie, R. (2016). Research Methods For Business: A Skill Building Approach. John Wiley \& Sons.

Shumbusho, R., Henry, D., \& Sharon, Z. (2020). Youth underrepresentation as a barrier to sexual and reproductive healthcare access in Kasulu district, Tanzania: A qualitative thematic analysis. International Journal of Public Health, 65(4), 391-398. https://doi.org/10.1007/s00038-020-01367-6

Stanford-Blair, N., \& Dickmann, M. H. (2005). Leading coherently: Reflections from leaders around the world. Sage.

Strodtbeck, F. L., \& Mann, R. D. (1956). Sex Role Differentiation in Jury Deliberations. Sociometry, 19(1), 3-11. https://doi.org/10.2307/2786099

Swanson, J. L., \& Woitke, M. B. (1997). Theory into practice in career assessment for women: Assessment and interventions regarding perceived career barriers. Journal of Career Assessment, 5, 443-462.

Thanacoody, P. R., Bartram, T., Barker, M., \& Jacobs, K. (2006). Career progression among female academics: A comparative study of Australia and Mauritius. Women in Management
Review, 21(7)
536-553. https://doi.org/10.1108/09649420610692499

Tlaiss, H., \& Kauser, S. (2010). Perceived organizational barriers to women's career advancement in Lebanon. Gender in Management: An International Journal, 25(6), $462-496$. https://doi.org/10.1108/17542411011069882

United Nation World Tourism Organization. (2010). Global Report on Women in Tourism 2010. Madrid: World Tourism Organization and UN Women.

Walsh, J. (2012). Not Worth the Sacrifice? Women's Aspirations and Career Progression in Law Firms. Gender, Work \& Organization, 19(5), 508-531. https://doi.org/10.1111/j.1468-0432.2012.00607.x

White, K. (2003). Women and Leadership in Higher Education in Australia. Tertiary Education and

$$
\text { Management, 9(1), 45-60. }
$$

https://doi.org/10.1023/A:1022218403113

Wilson, F. (2005). Caught between difference and similarity: the case of women academics. Women in Management Review, 20(4), 234-248. https://doi.org/10.1108/09649420510599061

Winslow, S., \& Davis, S. N. (2016). Gender Inequality Across the Academic Life
Course.
Sociology
Compass,
$10(5)$
$404-416$. https://doi.org/10.1111/soc4.12372

Wood, G. (2008). Gender stereotypical attitudes: past, present and future influences on women's career advancement. Equal Opportunities International, 27, 613- 628. 